\title{
books reviews
}

\author{
Acta Crystallographica Section D \\ Biological \\ Crystallography
}

ISSN 0907-4449

\section{books received}

The following books have been received by the Editor. Brief and generally uncritical notices are given of works of marginal crystallographic interest; occasionally, a book of fundamental interest is included under this heading because of difficulty in finding a suitable reviewer without great delay.

Crystallography made crystal clear (2nd edition). By Gale Rhodes. London: Academic Press, 2000. Pp. xix $+269+$ 21 colour plates. Price $£ 29.95$ (paperback) ISBN 0125870728.

The first edition of this useful little guide for the non-specialist was reviewed in this journal by Michal Sabat [Acta Cryst. (1995), D51, 1103]. This second edition corrects a number of errors in the original and adds two new chapters: Other diffraction methods, dealing with diffraction of neutrons and electrons, diffraction by fibres and amorphous materials, as well as Laue diffraction and time-resolved crystallography, and

\section{book reviews}

Works intended for this column should be sent direct to the Book-Review Editor, whose address appears in this issue. All reviews are also available from Crystallography Journals Online, supplemented where possible with direct links to the publisher's information.

Other kinds of macromolecular models, dealing with the results of NMR studies, homology models and other theoretical models. Leaving aside the author's somewhat eccentric view that there is little difference between experimental and theoretical models, the book is a good first introduction for the begining student and a helpful overview for other structural scientists. However, visualizing the otherwise excellent stereo plates without a viewer is no easier than it was with the first edition; the publisher would do well to include one.

Crystallization of nucleic acids and proteins: a practical approach (2nd edition). Edited by A. Ducruix and R. Giegé. Oxford University Press, 1999. Pp. $x x i i i+435$. Price $£ 35.00$ (paperback), $£ 70.00$ (hardcover). ISBN 0-19-963678-8 (paperback), 0-19-963679-6 (hardcover).

The first edition of this valuable handbook was reviewed in this journal by Dr Patricia
Weber [Acta Cryst. (1994), D50, 112]. This new edition contains revisions of most of the 14 original chapters, sometimes with different co-authors, and adds three new chapters to replace two of those in the original and to expand a third. The chapters dropped are those on automation of crystallization procedures and that on the physical chemistry of protein crystallization. Their replacements include a chapter by $\mathrm{S}$. Veesler and R. Boistelle entitled Diagnostic (sic) of pre-nucleation and nucleation by spectroscopic methods and background on the physics of crystal growth and one by A. Brisson, O. Lambert and W. BergsmaSchutter on Two-dimensional crystallization of soluble proteins on planar lipid films. The material in the first edition on selenomethionyl proteins has been incorporated in a new chapter by P. F. Berne, S. Doublié and C. W. Carter Jr, entitled Molecular biology for structural biology, which also deals with protein-expression systems and engineering the physical properties of macromolecules. 